\title{
Analysis of Dickens' Critique and Humanity Spirit in Oliver Twist Based on the Appraisal Theory
}

\author{
Min Lian \\ Shanxi Normal University, China
}

\begin{abstract}
As the greatest representative of English critical realism, Charles Dickens' novel Oliver Twist reflects the complex social reality in his time and manifests the author's humanity spirit especially to the poor and the lower class. The paper uses the attitude sub-system in appraisal theory as analytical framework, chooses the attitude resources related to the protagonist Oliver as research material, mainly analyzes his personality characteristics at lexical level. The study aims to reveal the author's humanity spirit that lurked in the discourse after construing Oliver's image in that social background and his critique spirit to the society, in the hope of deepening our understanding of the significance of the theme of the novel, and providing a linguistic reference for the appreciation of literature work. At the same time, this study further confirms the value of appraisal theory in discourse analysis and appreciation.
\end{abstract}

Index Terms—appraisal theory, attitude system, Dickens, Oliver Twist, benevolent spirit, critical spirit

\section{INTRODUCTION}

Oliver Twist, as one of the most famous works of Charles Dickens', is a novel reflecting the darkness, terror, violence and deception in London society in that time. As a typical representative of the poor group in the novel, the author used a large number of words and sentences describing Oliver's life experiences who has suffered so many misfortunes and unfair treatments since he was born, but did not lose his kind nature and perseverance. The little boy was loved by nice people and finally lived a happy life. The author highlights the critical spirit to the dark society and benevolence spirit especially to the poor and the lower class in this novel.

As the new development of systematical functional linguistics, appraisal theory was put forward by Australian linguist James R. Martin in 1990s. Which studies how speakers or writers express their own attitudes in language and achieve interpersonal interaction with listeners or readers. Appraisal theory has a good operability in appreciating literature work which evaluates the language users' ideology and attitude by evaluative lexis. While the text-theme is construed by lexical grammar, and the positive or negative expression of the theme will affect the expression of the lexical grammar. Therefore, the paper construes the image of Oliver based on attitude system in appraisal theory, after analyzing the words and expressions that relate to Oliver, further reveals the author's sympathy and support to the poor, as well as his critical spirit to the dark and deteriorating society.

\section{LITERATURE REVIEW}

As one of the most famous works of Charles Dickens', Oliver Twist has been studied from different perspectives in the past few years. After retrieving the key word 'Oliver Twist' in CNKI, the author finds the studies on Oliver Twist can be roughly divided into the following 4 aspects: 1. Xia Jiao (2017), Li Yun (2016), Ding Man (2015) and Li Changhong \& Zeng Biao (2015) conducted studies on the image analysis of characters in the novel mainly form the literature angle; 2. Guo Yinyan (2017), Zhang Suona (2016), Li Tianran (2014), Zheng Meina (2012) and Tang Yunke \& Yang Zhenghe (2006) etc. explored the theme of the novel also form the angle of literature appreciation; 3. Lei Yu (2012) and Chen Li (2009) studied the novel from language translation angle and conducted a comparative study on the English and Chinese versions of the novel; 4. The author analyzed the novel from the perspective of pragmatics in linguistics in 2016, and mainly revealed the conversational implicature by using cooperative principle and politeness principle. While few researchers or scholars study the novel from the perspective of appraisal theory in systematical functional linguistics, which as a powerful tool of discourse analysis.

As one of three major discourse semantic resources construing interpersonal meaning, appraisal itself is regionalised as three interacting domains - attitude, engagement and graduation. The theory studies how speakers or writers express their own attitudes in language and achieve interpersonal interaction with listeners or readers, which has been used to analyze different discourses. After searching for the key word 'appraisal theory' in CNKI, the author finds the research results can be divided into the following 5 aspects: 1. Jiang Guodong \& Chen Xu (2017), Wang Zhiwei (2017), Lai Yan \& Xin Bing (2012) and Zhang Lingyu \& Yang Fengling (2011) conducted studies on the news discourse based on appraisal theory; 2. Yuan Xiaomin (2017), Liu Qinyun \& Han Geling (2017), Liu Song \& Luo Xiujuan (2017), Chen Lingjun \& Zhao Chuang (2016), Yang Xiaohong (2013) and Peng Guoshun (2010) studied the political discourse based on the analytical framework of appraisal system; 3. Zhu Qian (2017), Zhang Wanying (2016), Fu Shujing (2016), Chen Mei \& Wen Jun 
(2013) and Hu Qin \& Liu Kongxi (2008) using the appraisal theory analyzed and appreciated the literature works; 4. Li Zhanzi \& Hu Mingxia (2016) and Yu Tao \& Wang Yun (2009) analyzed the academic lectures by using the appraisal theory; 5. Yang Pan (2012) and Qian Hong (2007) conducted studies on the translation of advertising language and slogans from the angle of appraisal theory. As a powerful analytical tool of discourse analysis, appraisal theory provides us with a good analytical framework of literature appreciation. While few researchers study the novel Oliver Twist from the angle of appraisal theory. Therefore, the paper uses the attitude sub-system in appraisal theory as analytical framework, chooses the attitude resources related to the protagonist Oliver as research material, mainly analyzes his personality characteristics at lexical level, and aims to reveal the author's benevolent spirit that lurked in the discourse.

\section{THEORETICAL BASES}

Appraisal theory was put forward by Australian linguist James R. Martin in 1990s, which studies how speakers or writers express their own attitudes in language and interact with listeners or readers. Appraisal itself is regionalised as three interacting domains - attitude, engagement and graduation (J. R. Martin \& P. R. R. White, 2005). Among which the attitude sub-system is at the heart of the whole system, which involves three semantic regions covering what is traditionally referred to as emotion, ethics and aesthetics, now referred to as affect, judgement and appreciation. Here in the following part, we will introduce the three sub-systems one by one.

\section{A. Affect Sub-system}

Emotion is arguably at the heart of the three semantic regions since it is the expressive resource we are born with and embody physiologically from almost the moment of birth (Painter, 2003). This emotive dimension of meaning is referred to as affect. And along with it there comes the judgement and appreciation sub-systems. Affect is the emotion or reacting to behaviour, text, process or phenomena, which is concerned with registering positive and negative feelings: do we feel happy or sad, confident or anxious, interested or bored? (J. R. Martin \& P. R. R. White, 2005) People tend to express themselves in positive words when they are in a good humor, while express themselves in negative words when in a bad skin.

\section{B. Judgement Sub-system}

Judgement belongs to ethics category, which deals with attitudes towards behaviour, which we admire or criticize, praise or condemn (J. R. Martin and P. R. R. White, 2005). In general terms judgement can be divided into those dealing with 'social esteem' and those oriented to 'social sanction'. Judgement of esteem have to do with 'normality' (how unusual someone is), 'capacity' (how capable they are) and 'tenacity' (how resolute they are); judgement of sanction have to do with 'veracity' (how truthful someone is) and 'propriety' (how ethical someone is) (J. R. Martin \& P. R. R. White, 2005).

\section{Appreciation Sub-system}

Appreciation involves evaluations of semiotic and natural phenomena, according to the ways in which they are valued or not in a given field. In general terms appreciations can be divided into our 'reactions' to things (do they catch our attention; do they please us?), their 'composition' (balance and complexity), and their 'value' (how innovative, authentic, timely, etc.) (J. R. Martin \& P. R. R. White, 2005).

\section{ANALYSIS AND DISCUSSION}

Dickens lived a tragic life in his lifetime, which caused him has a strong sense of kindness to the poor at the bottom of the society. Oliver in the novel Oliver Twist as a representative of the poor and the social lower class, also lived a miserable life. On the basis of the three subsystems in attitude system, the paper mainly analyzes the discourse that relates to Oliver at the lexical level. There are 231 evaluative terms attitude involved in the research material, the detailed distribution is as follows.

\section{A. Affect Sub-system}

The research materials analyzed by affect sub-subsystem are mainly chosen from the following three parts: Chapters 1 to 4 ( which introduced Oliver's situation about birth, education, growth and board and so on; chapters 14 to 16 (which showed how very fond of Oliver Twist, the merry old Jew and Miss Nancy were); chapters 52 to 53 (the happy ending of Oliver's life). Emotion expression can be realized by quality modifier adjectives or adverbial phrases, as well as the verbs in mental process and behavioral process in functional linguistics. One the one hand, the author used lots of negative words to describe the social background and circumstance in which Oliver was born; while on the other hand, used more positive words rather than negative words to name the little boy Oliver, although there were a few negative expressions in describing his early life in terms of his birth, growth, board etc.

Example 1:

'For a long time after he was ushered into this world of sorrow and trouble, by the parish surgeon, it remained a matter of considerable doubt whether the child would survive to ...' (Dickens, 2009) 
In this example chosen from chapter one, when the author described the social environment of Oliver's birth to us, he used the negative expressions 'sorrow and trouble'. Typically, the two words are used to describe people's mood or temper, here they are used to describe the world or the society. It seems that they are endowed with a kind of specific meaning by the author, and implies that Oliver was born to be tortured by such a social environment. On the surface, the expression is negative, but not as negative as it appeared, the author actually is expressing his sympathies to the little boy and transmitting a positive energy to the dark society.

Example 2:

'For the next eight or ten months, Oliver was the victim of a systematic course of treachery and deception.' (Wang Xun \& Ji Fei, 2009)

In this example chosen from chapter 2, out of the same feeling or emotion, the author also used the negative words 'course of treachery and deception' to describe the world and society Oliver will come down to. Oliver has been a victim of the social system and environment since he was born. The expressions accord with the theme of the novel that the weak group were always bullied and decepted. At the same time, the deteriorating social phenomena was criticized.

Example 3:

'Oliver ... a new burden having been imposed upon the parish...'; '...a parish child - the orphan of a workhouse-the humble half-starved drudge - to be cuffed and buffeted through the world, - despised by all, and pitied by none'. (Wang Xun \& Ji Fei, 2009)

In this example, the author told us Oliver was born and survived. And subsequently he became a new burden of the parish. The negative expressions 'new burden', 'orphan of a workhouse', 'humble half-starved drudge' and 'cuffed and buffeted' etc all reflect the little boy Oliver's plight. It seems that the guilty was should be imposing to Oliver although he did nothing. Which implies the unfair treatment Oliver suffered.

Example 4:

'a dear young lamb', 'my dear child', 'little Oliver', 'good boy', 'poor Oliver', 'a nice looking boy', 'my dear', 'sweet face', 'weeping bitterly' (Wang Xun \& Ji Fei, 2009)

There were so many good names for Oliver in this example chosen from chapters 2 and 3. Mr. Bumble called him 'little Oliver' and 'good boy' with the tone of love and brought him to find a job. And it seemed that the adjectives 'poor' expressed the author's sympathetic feeling to the little boy. On the one hand, the author chose the noun phrases 'dear young lamb', 'my dear child', 'good boy', 'a nice looking boy', and 'sweet face' etc expressed his sympathies and love to the poor boy. On the other hand, the expression 'weeping bitterly' not only reflects Oliver's sadness and the author's sympathy to him, but also expressed the cruelty of the society, the little childs even became the tool for criminal purpose.

Example 5:

'A porochial' prentis, who is at present a deadweight, a millstone, as I may say; round the porochial throat?...'; '....and was in a fair way of being reduced, for life, to a state of brutal stupidity and sullenness by the ill usage he had received.' (Wang Xun \& Ji Fei, 2009)

In this example, the expressions 'deadweight', 'millstone' and 'brutal stupidity and illness' all relate to Oliver, who is disliked and avoided by the parish people. The expressions not only showed the author's deep sympathy to the poor boy in an explicit way, but also disclosed and criticized the cruelty and ugliness in the real world. Both of them are the main theme of the novel, which deepens our standing of the significance of the literature work from the lingyuistics perspective.

\section{B. Judgement Subsystem}

The research materials in this part are mainly chosen from chapters 6 and 7 (the author described the process Oliver was irritated and resulted by Noah as well as his rebellion to the unfair treatment). Actually as the weakest group and most difficult group in the society, Oliver has been bearing the injustice from the beginning, he just could not tolerate people insulting his mother, so his rebellious spirit comes from his nature, just as the author described 'his spirit was roused at last; the cruel insult to his dead mother had set his blood on fire'. Therefore, in this part, the author chose many negative words to describe Noah with the purpose of implying Oliver's tenacity or refractory as well as his support and sympathy to the little boy.

Example 6:

'Crimson with fury, Oliver started up; overthrew the chair and table; seized Noah by the throat; shook him, in the violence of his rage, till his teeth chattered in his head; collecting his whole force into one heavy blow, felled him to the ground.' (Wang Xun \& Ji Fei, 2009)

In this sentence, it sounds the verbs 'shook', 'chattered' and 'felled' full of the negative attitude of violence, but the implied meaning is that Oliver was forced to do these but not out of his own free will. The word 'anger' could serve as an enough evidence for his rebellious act. Therefore, his rebellion is a reasonable way of relieving his feelings accumulated in the unfair treatments. At the same time, the author expressed his sympathy to the weak boy here in an implicit way.

Example 7:

'But his spirit was roused at last; the cruel insult to his dead mother had set his blood on fire. His breast heaved; his attitude was erect; his eye bright and vivid; his whole person changed, as he stood glaring over the cowardly tormentor who now lay crouching at his feet; and defied him with an energy he had never known before. (Wang Xun \& Ji Fei, 2009)

When Noah referred to his dead mother and said something bad about her, the author used so many adjectives and verbs to describe Oliver's response, 'heaved', 'erect', 'bright and vivid', 'changed' 'defied' and 'an energy had never 
known before'. Actually, there is no distinct attitude involved in these expressions, while in this context, they are invested with positive meaning that Oliver is kind and strong-minded in nature. The adjectives 'bright' and 'vivid' showed his extreme anger swelling in his heart. Maybe the energy exploded at that moment was not realized even by himself. Therefore, the blame for the rebellious act should not be thrust upon him because it is not his guilty but out of his love to mother.

Example 8:

'You've raised an artificial soul and spirit in him, ma'am, unbecoming a person of his condition...'; '"No!' replied Oliver, boldly". (Wang Xun \& Ji Fei, 2009)

In this case, the expression 'an artificial soul and spirit' reflects the author's high praise for Oliver. In the face of result, the rebellious spirit was awakened in the child's heart, he is not weak anymore. In the same way, the bold response 'no' presented a brave image to us. The author expressed his positive feelings to Oliver, who is becoming stronger after experiencing such tribulation.

Example 9:

'He had listened to their taunts with a look of contempt; he had borne the lash without a cry: for he felt that pried swelling in his heart which would have kept down a shriek to the last, though they had roasted him alive.' (Wang Xun \& Ji Fei, 2009)

In this example, when the author described the inner inspect of Oliver, he used the expressions 'a look of contempt','borne the lash without a cry' and 'pride swelling in his heart', all of these expressions suggest that the author holds a positive attitude to Oliver's rebellion. Although suffered distress and misfortunes, he still took strong character and never yield to the dark and deteriorating social environment.

Example 10:

'Oh! God forgive this wretched man!' cried the boy with a burst of tears.(Wang Xun \& Ji Fei, 2009)

In this case, when Oliver went to visit the prisoner old Jew, he cried with a burst of tears, the two words 'wretched' and 'forgive' in the sentence 'God forgive this wretched man' present a kind image to us. Although experienced a very tragic life and was cheated by the old Jew, Oliver did not lose his nature and still keep his kindness to the old man and the world. Therefore, in this part, the author expressed his positive feelings explicitly or implicitly to Oliver by using these attitudinal words .

Example 11:

'That Oliver Twist was moved to resignation by the example of these good people, I cannot, although I am his biographer, undertake to affirm with any degree of confidence; but I can most distinctly say, that for many months he continued meekly to submit to the domination and ill-treatment of Noah Claypole...' (Wang Xun \& Ji Fei, 2009)

The meaning of the sentence is that although Oliver has been dominated and treated unfairly for several months, the author is not sure whether he will struggle against violent repression of those 'good' people or not. The implied meaning is that as a member of the vulnerable groups in the society with such background, maybe he dared not voice his dissatisfaction or did not have the strength to resist. Here the word 'good' is used ironically to express the cruelty and atrocity. Actually, the author showed a kind of sympathetic feeling to the poor boy as well as the criticism to the dark society.

\section{Appreciation Subsystem}

The research materials in this part are mainly chosen from chapter 14 (In this part, the author narrated the situation Oliver lived in the good man Mr. Brownlow's home as well as the argument between Mr. Brownlow and Mr. Grimwig brought about by Oliver. ) and chapter 30 (relates what Oliver's new visitors thought of him). After analyzing the vocabularies in the chosen text, we can infer the positive attitude and affection the author held to Oliver.

Example 12:

" 'I'll swear he is not,' replied Mr. Brownlow, warmly.'

' I'll answer for that boy's truth with my life!' said Mr. Brownlow, knocking the table'.

(Wang Xun \& Ji Fei, 2009)

Here from the words 'swear' and 'knock' it can be seen that the fight between Mr. Brownlow and Mr. Grimwig is becoming more and more fierce. In fact, they are arguing about Oliver's nature whether he will cheat the good man Mr. Brownlow. Mr. Brownlow said he would swear with his life. It can be seen that the little boy Oliver is beloved and trusted by the good man deeply, who treated him kindly and passionately. Therefore, the author showed his tender affection and compassion to the little boy again.

Example 13:

' think how young he is; think that he may never have known a mother's love, or the comfort of a home; that ill-usage and blows, or the want of bread, may have driven him to herd with men who have forced him to guilt'. (Wang Xun \& Ji Fei, 2009)

In this example, when Rose and the elder lady talked about whether Oliver was a thief, the young lady Rose used the two words 'driven' and 'forced' which reflect Oliver's innocence. She cited numerous reasons to request and persuade the elder lady not to harm him. As a result, the woman agreed with a free will. The author intended to tell us that Oliver as the 
victim of such a rotten society, he was cheated and forced to do something bad even it was not realized by himself. Actually, he was expressing his sympathies to the weak group as well as the criticism to the society in that time.

Example 14:

'What can this mean?' exclaimed the elder lady. 'This poor child can never have been the pupil of robbers!'

...

'But, can you - really believe that this delicate boy has been the voluntary associate of the worst outcasts of society?' said Rose, anxiously. (Wang Xun \& Ji Fei, 2009)

In this example, Rose, the elder lady and the doctor were talking about whether Oliver is the associate partner of the worst group, in the answers, the elder lady mentioned a word 'never' and Rose referred to the word 'really', here both of them are embodied the meaning of positive attitude. It is not hard to see although there is some skepticism the doctor's inner heart, more people trust Oliver deeply. Here the author expressed his positive feeling to the little boy Oliver through these two adverbs of degree.

\section{CONCLUSION}

After analyzing the discourse which relates to Oliver, combined with the analytical framework of attitudinal system in appraisal system put forward by James Martin, the study found that attitude system can construe the author Dickens' emotional involvement and the theme of the novel effectively, and the affect system and judgement system attitudinal resources contain a big percentage compared with the appreciation system in attitudinal resources, which is connected with the novel type as well as the theme of the novel. In the description of Oliver, the positive evaluative lexis account for a big percentage, which revealed that the author expressed more positive affections rather than negative feelings to the little boy Oliver. The latent thought of the novel i,e. Dickens' humanity spirit to the poor and his critique spirit to the society was revealed under the analysis of the appraisal system. According to this study, the author interacts with the readers indirectly, which realizes the new development of the discourse comprehension in terms of interpersonal meaning. As a representative of the poor, although experienced misfortunes, he was still very kind to others and without complaint at anyone. Which are realized through the author's depiction and readers' evaluation and analysis. In this view, the attitude system in appraisal theory provides a new method for the interpretation of text discourse, and it is worthy to be applied and popularized in literature appreciation.

\section{REFERENCES}

[1] Charles Dickens. (2000). Oliver Twist. Harbin: Harbin Press.

[2] Gee. J. (2011). An Introduction to Discourse Analysis: Theory and Method. London: Routludge.

[3] Harris, Z. (1952). Discourse Analysis. Language, (28): 1-30.

[4] Hu Zhuanglin. (2009). Study on the Evaluation of Discourse. Foreign Language Teaching, (1): 1-6.

[5] J. R. Martin \& Rose, David. (2003). Working with Discourse: Meaning Beyond the Clause. London: Continuum.

[6] J. R. Martin \& P. R. R. White. (2005). The Language of Evaluation: Appraisal in English. England: Palgrave Macmillan.

[7] Lian Min. (2017). Discourse Analysis of Oliver Twist from the Perspective of Pragmatics. Theory and Practice in Language Studies, (7): 626-632.

[8] Liu Jinsheng, liu Lihua. (2012). Research on Discourse Analysis from the Perspective of Evaluation. Journal of Tsinghua University (Natural Science), (2): 134-141.

[9] Liu Shizhu. (2010). The Development of Evaluation Theory in China. Foreign Language and Foreign Language Teaching, (5): 33-37.

[10] Rong Rude. (2006). Oliver Twist. Shanghai: Shanghai Translation Publishing House.

[11] Wang Xun \& Ji Fei. (2009). Oliver Twist. Beijing: Tsinghua University Press.

[12] Wang Zhenhua (2006). Evaluation System and Its Operation. Foreign Language, (1): 15-17.

Min Lian, was born in Lianfen, China in 1992. She received her Bachelor's degree in English from Lvliang University, China in 2016.

She is currently a postgraduate in Shanxi Normal University, Linfen, China. Her research interests include English and American literature and culture. She has published her two articles in international journals "Theory and Practice in Language Studies" in August 2017 and "Journal of Language Teaching and Research" in January 2018. 